\title{
ARTICLE
}

Received 2 Feb 2015 | Accepted 17 Jun 2015 | Published 24 Jul 2015

DOl: $10.1038 /$ ncomms 8843

OPEN

\section{The water catalysis at oxygen cathodes of lithium-oxygen cells}

Fujun $\mathrm{Li}^{1,2}$, Shichao $\mathrm{Wu}^{1}$, De $\mathrm{Li}^{1}$, Tao Zhang ${ }^{1}$, Ping $\mathrm{He}^{3}$, Atsuo Yamada ${ }^{2} \&$ Haoshen Zhou ${ }^{1,2,3}$

Lithium-oxygen cells have attracted extensive interests due to their high theoretical energy densities. The main challenges are the low round-trip efficiency and cycling instability over long time. However, even in the state-of-the-art lithium-oxygen cells the charge potentials are as high as $3.5 \mathrm{~V}$ that are higher by $0.70 \mathrm{~V}$ than the discharge potentials. Here we report a reaction mechanism at an oxygen cathode, ruthenium and manganese dioxide nanoparticles supported on carbon black Super P by applying a trace amount of water in electrolytes to catalyse the cathode reactions of lithium-oxygen cells during discharge and charge. This can significantly reduce the charge overpotential to $0.21 \mathrm{~V}$, and results in a small discharge/charge potential gap of $0.32 \mathrm{~V}$ and superior cycling stability of 200 cycles. The overall reaction scheme will alleviate side reactions involving carbon and electrolytes, and shed light on the construction of practical, rechargeable lithium-oxygen cells.

\footnotetext{
${ }^{1}$ Energy Interface Technology Group, National Institute of Advanced Industrial Science and Technology (AIST), 1-1-1, Umezono, Tsukuba 305-8568, Japan. ${ }^{2}$ Department of Chemical System Engineering, The University of Tokyo, 7-3-1, Hongo, Bunkyo-ku, Tokyo 113-8656, Japan. ${ }^{3}$ National Laboratory of Solid State Microstructures \& College of Engineering and Applied Sciences, Nanjing University, Nanjing 210093, China. Correspondence and requests for materials should be addressed to H.Z. (email: hs.zhou@aist.go.jp or hszhou@nju.edu.cn).
} 
T he $\mathrm{Li}-\mathrm{O}_{2}$ cells are operated with oxygen reduction to produce $\mathrm{Li}_{2} \mathrm{O}_{2}$ and its reverse oxidation to release $\mathrm{Li}^{+}$ions and oxygen at cathodes $\left(2 \mathrm{Li}^{+}+\mathrm{O}_{2}+2 \mathrm{e}^{-} \leftrightarrow \mathrm{Li}_{2} \mathrm{O}_{2}\right.$, $\left.E^{\circ}=2.96 \mathrm{~V} \mathrm{vs}^{+}{ }^{+} / \mathrm{Li}\right)$ in discharging and charging processes, respectively ${ }^{1-3}$. The intrinsic chemical and physical nature of $\mathrm{Li}_{2} \mathrm{O}_{2}$ and its intermediates can lead to instability of other cell components, such as carbon supports $(>3.50 \mathrm{~V})^{4}$ and electrolytes, and formation of detrimental byproducts, typically $\mathrm{Li}_{2} \mathrm{CO}_{3}$ and lithium alkyl carbonates ${ }^{4-9}$. They can subsequently induce high overpotentials in both discharging and charging processes and eventually discharge/charge failure during cycles $^{4-13}$. A lot of efforts have been made to address these issues, but there are still many challenges for a practical $\mathrm{Li}-\mathrm{O}_{2}$ cell $^{4-14}$

The success of deploying $\mathrm{Li}-\mathrm{O}_{2}$ cells in the future will be crucially dependent on how small the overpotentials at the cathode side can be reduced and how many cycles they can work reversibly ${ }^{15-17}$. Currently, two strategies have been widely applied for these issues. One is to use carbon-free or carbon-alternative cathodes, like nanoporous gold ${ }^{10}, \mathrm{TiC}^{11}$ and conductive metal oxide supported $\mathrm{Ru}^{12,13}$, which can circumvent side reactions involving carbon. The charge overpotentials ensuring the decomposition of $\mathrm{Li}_{2} \mathrm{O}_{2}$ are reduced to $\sim 0.54 \mathrm{~V}$, corresponding to charge potentials of $\sim 3.50 \mathrm{~V}$ (refs 10-13). This direct electrochemical oxidation of $\mathrm{Li}_{2} \mathrm{O}_{2}$ was revealed to involve multiple processes, in which the initial delithiation occurring at an overpotential of $0.44 \mathrm{~V}$, possibly suggests the theoretical limit $^{18,19}$. Alternatively, redox mediators have been introduced to chemically oxidize $\mathrm{Li}_{2} \mathrm{O}_{2}$ and the apparent charge potentials are typically determined by the mediators. For instance, tetrathiafulvalene and LiI reduce the charge potential to $\sim 3.50 \mathrm{~V}$, equal to a charge overpotential of $0.54 \mathrm{~V}$ (refs 20-23). In principle, $\mathrm{Li}_{2} \mathrm{O}_{2}$ can be oxidized by mediators possessing higher redox potentials than its equilibrium potential; however, practical mediators are very limited. A more efficient and compatible one for further potential reduction is still lacking. By either the direct or indirect (mediators) $\mathrm{Li}_{2} \mathrm{O}_{2}$ oxidation strategy, it will be a great challenge to reduce the charge potentials to feasible values. Exploring new reaction mechanisms at the oxygen cathodes to significantly improve the round-trip efficiency and cycling stability is essential and urgently necessary for the development of $\mathrm{Li}-\mathrm{O}_{2}$ cells.

Although water in electrolytes has been found to affect the morphologies of discharge products and increase the discharge capacity ${ }^{24-26}$, its presence in electrolytes or $\mathrm{O}_{2}$ atmosphere resulted in rapid charge potential increase and hence cell death after several cycles $^{26-28}$. In addition to the main discharge product $\mathrm{Li}_{2} \mathrm{O}_{2}$, a byproduct $\mathrm{LiOH}$ was also detected ${ }^{27}$. We found that the decomposition of $\mathrm{LiOH}$ is strongly related to the applied catalysts, such as Ru nanoparticles supported on Super P (Ru/SP). To reduce the charge overpotentials of $\mathrm{Li}-\mathrm{O}_{2}$ cells, a trace amount of water in electrolytes and electrolytic mangnese oxide (EMD, $\gamma$ $\mathrm{MnO}_{2}$ ) nanoparticles are both utilized to favour the transformation of the discharge product from $\mathrm{Li}_{2} \mathrm{O}_{2}$ to $\mathrm{LiOH}$ and its following decomposition on charging. The $\mathrm{MnO}_{2}$ incorporated in $\mathrm{Ru} / \mathrm{SP}\left(\mathrm{Ru} / \mathrm{MnO}_{2} / \mathrm{SP}\right)$ also allows for the water regeneration at the cathode during the discharge/charge cycles. This enables the $\mathrm{Li}-\mathrm{O}_{2}$ cell to operate with a small discharge/ charge potential gap and superior cycling stability. A reaction mechanism by converting $\mathrm{Li}_{2} \mathrm{O}_{2}$ to $\mathrm{LiOH}$ in the presence of both water and $\mathrm{Ru} / \mathrm{MnO}_{2} / \mathrm{SP}$ is proposed.

\section{Results}

Low overpotentials at $\mathrm{Ru} / \mathrm{MnO}_{2} / \mathrm{SP}$. The $\mathrm{Li}-\mathrm{O}_{2}$ cells were constructed with $\mathrm{Ru} / \mathrm{MnO}_{2} / \mathrm{SP}$ pressed onto a carbon paper as cathodes, $0.5 \mathrm{M} \mathrm{LiClO}_{4}$ in DMSO containing 120 p.p.m. of $\mathrm{H}_{2} \mathrm{O}$ as electrolytes and $\mathrm{LiFePO}_{4}$ in replacement of $\mathrm{Li}$ anodes. The $\mathrm{LiFePO}_{4}$ is not a practical anode, but is able to avoid the reaction of $\mathrm{Li}$ metal and the trace amount of $\mathrm{H}_{2} \mathrm{O}$ and any contamination from formation of the solid electrolyte interface layer on the $\mathrm{Li}$ anode $^{20}$. It has a stable potential of $\sim 3.45 \mathrm{~V} \mathrm{vs} \mathrm{Li}^{+} / \mathrm{Li}$ regardless of the state of charge and favours the investigation on the discharge/charge behaviour in the presence of $\mathrm{H}_{2} \mathrm{O}$ and the underlying reaction mechanism specifically at the oxygen cathode. The discharge/charge potentials at the oxygen cathode of the $\mathrm{Li}-\mathrm{O}_{2}$ cells are converted to against $\mathrm{Li}$ for discussion.

The carbon paper has been demonstrated to have negligible contribution to cell performance (Supplementary Fig. 1; Supplementary Note 1). The $\mathrm{Li}-\mathrm{O}_{2}$ cell with $\mathrm{Ru} / \mathrm{MnO}_{2} / \mathrm{SP}$ as cathode and the DMSO-based electrolyte containing p.p.m.-leveled $\mathrm{H}_{2} \mathrm{O}$ is discharged and charged at $500 \mathrm{mAg}^{-1}$ (corresponding to $0.71 \mu \mathrm{A} \mathrm{cm}^{-2}$ based on the BrunauerEmmett-Teller, (BET) surface area of $\mathrm{Ru} / \mathrm{MnO}_{2} / \mathrm{SP}$ ) as shown in Fig. 1a. A charge potential plateau as low as $\sim 3.20 \mathrm{~V}$, corresponding to an overpotential of $\sim 0.24 \mathrm{~V}$, can be clearly observed. Its corresponding $d Q / d V$ curve in Fig. $1 b$ shows sharp oxygen reduction reaction and oxygen evolution reaction peaks in the discharging and charging process, respectively, which are consistent with the flat discharge and charge plateaus. In addition, a small plateau at $\sim 3.60 \mathrm{~V}$ is also obtained in the charge profile in Fig. 1a. It could be resulted from the affinity of DMSO with the
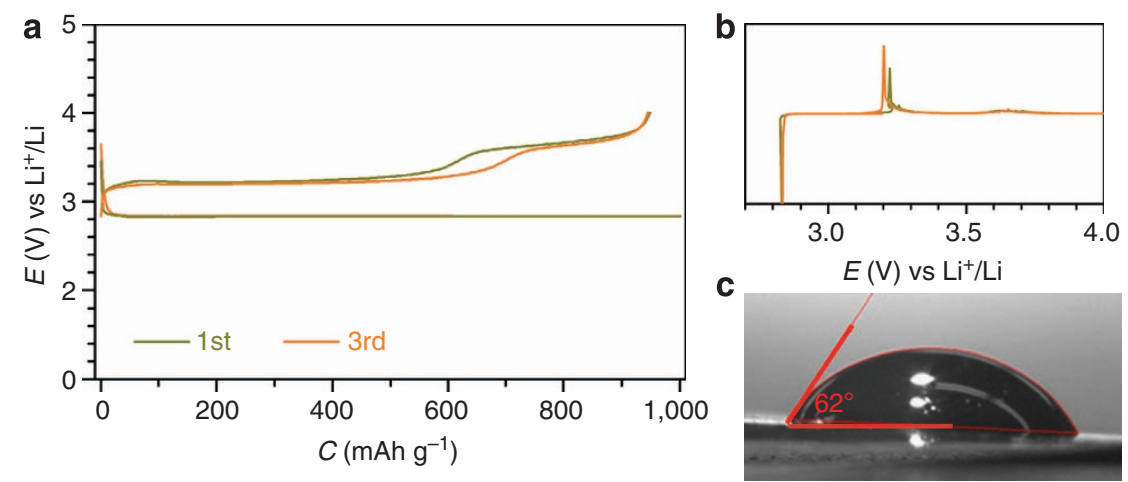

Figure 1 | Initial three cycles of discharge and charge. (a) Discharge/charge profiles of the $\mathrm{Li}_{-} \mathrm{O}_{2}$ cells with a configuration of (Ru/MnO $\left.2 / \mathrm{SP}\right) /$ electrolyte/ $\mathrm{LiFePO}_{4}$. The electrolyte is $0.5 \mathrm{M} \mathrm{LiClO}_{4}$ in $\mathrm{DMSO}$ with 120 p.p.m. $\mathrm{H}_{2} \mathrm{O}$. (b,c) The corresponding dQ/dV curves and the contact angle of the electrolyte on the cathode. The discharge and charge cutoffs are $1,000 \mathrm{mAhg}^{-1}\left(5,099 \mu \mathrm{Cm}^{-2}\right.$ based on the BET surface area of Ru/MnO$\left./ \mathrm{SP}\right)$ and $4.0 \mathrm{~V}$, respectively. The potentials against $\mathrm{Li}^{+} / \mathrm{Li}$ are converted from $\mathrm{LiFePO}_{4}$. Rate: $500 \mathrm{mAg}^{-1}$-based on the total weight of $\mathrm{Ru}, \mathrm{MnO}_{2}$ and $\mathrm{SP}$, corresponding to $0.71 \mu \mathrm{A} \mathrm{cm}^{-2}$; loading: $\sim 0.5 \mathrm{mg} \mathrm{cm}^{-2}$. 
$\mathrm{Ru} / \mathrm{MnO}_{2} / \mathrm{SP}$ cathode that has a large contact angle of $62^{\circ}$, compared with the discharge and charge profiles of the $\mathrm{Li}-\mathrm{O}_{2}$ cell with a dimethoxyethane-(DME-)-based electrolyte and the good wettability of DME on the cathode in Supplementary Fig. 2. This may enable the oxygen evolved in a charging process to accumulate in the voids between the residual discharge product and the cathode, as schematically described in Supplementary Fig. 3 and Supplementary Note 2. It would induce slow diffusion of electrolytes into the voids for the decomposition of the remaining discharge products and result in the relatively large overpotential at $\sim 3.60 \mathrm{~V}$, which is not observed in the affinitive DME-based electrolyte (Supplementary Fig. 2). Similar observations are also obtained in the other kinds of electrolytes, such as triglyme (G3)- and tetraglyme (G4)-based electrolytes (Supplementary Fig. 4). The trace amount of $\mathrm{H}_{2} \mathrm{O}$ in electrolytes is demonstrated to play a crucial role on reducing charge overpotentials of $\mathrm{Li}-\mathrm{O}_{2}$ cells in all the widely used electrolytes, which was empirically considered as a negative factor in a Li-ion cell ${ }^{29}$.

Analysis on the discharged/charged cathode. The discharged and charged $\mathrm{Ru} / \mathrm{MnO}_{2} / \mathrm{SP}$ cathodes in the DMSO-based electrolyte containing water have been characterized by X-ray diffraction (XRD). As shown in Fig. 2a, the discharge products are identified as a mixture of $\mathrm{LiOH}$ and $\mathrm{Li}_{2} \mathrm{O}_{2}$, referring to the standard powder diffraction files of 01-085-0777 and 00-009-0355, respectively. The diffraction peaks of $\mathrm{LiOH}$ become sharper and stronger at the cathode with a discharge capacity of $4,000 \mathrm{mAh} \mathrm{g}^{-1}$ and addition of more electrolyte (Supplementary Fig. 5), suggesting more $\mathrm{LiOH}$ converted from $\mathrm{Li}_{2} \mathrm{O}_{2}$. To avoid the effect of $\mathrm{MnO}_{2}$, quantification of $\mathrm{LiOH}$ and $\mathrm{Li}_{2} \mathrm{O}_{2}$ was conducted on the $\mathrm{Ru} / \mathrm{SP}$ cathode with the same discharge capacity as in Fig. 1 via iodometric titration. The discharge product $\mathrm{Li}_{2} \mathrm{O}_{2}$ reacts with $\mathrm{H}_{2} \mathrm{O}$ via $\mathrm{Li}_{2} \mathrm{O}_{2(\mathrm{~s})}+2 \mathrm{H}_{2} \mathrm{O}_{(\mathrm{l})} \rightarrow$ $\mathrm{H}_{2} \mathrm{O}_{2(1)}+2 \mathrm{LiOH}_{(\mathrm{aq})} 30,31$, where $\mathrm{H}_{2} \mathrm{O}_{2}$ further oxidizes iodide to iodine, the titrated target. The $\mathrm{LiOH}$ and $\mathrm{Li}_{2} \mathrm{O}_{2}$ in the discharged cathode were titrated via two steps (Supplementary Figs 6 and 7; titration processes in Supplementary Methods) and estimated to 16.02 and $1.48 \mu \mathrm{mol}$, respectively, which are in agreement with the XRD patterns of the discharged cathode in Fig. 2a. The majority of $\mathrm{LiOH}$ formed at a discharged cathode is revealed by the characteristic absorbance peak in the infrared (IR) spectra in Fig. 2b. Based on the electrons passing through the cathode and the oxygen derived from the discharge products of $\mathrm{LiOH}$ and $\mathrm{Li}_{2} \mathrm{O}_{2}$ by iodometric titration, the discharging process is a $1.97 \mathrm{e}^{-} / \mathrm{O}_{2}$ process, quite close to the theoretical value of $2.00 \mathrm{e}^{-} / \mathrm{O}_{2}$. It is confirmed that in other electrolytes, like DME-, G3- and G4-based electrolytes, the discharging process is also a $\sim 2.00 \mathrm{e}^{-} / \mathrm{O}_{2}$ process, as listed in Supplementary Table 1. This suggests that $\mathrm{LiOH}$ is converted from $\mathrm{Li}_{2} \mathrm{O}_{2}$ via a chemical, not an electrochemical, process in the discharging processes.

After charge, the discharge products $\mathrm{LiOH}$ and $\mathrm{Li}_{2} \mathrm{O}_{2}$ were decomposed, as evidenced by the disappearance of their characteristic diffraction peaks in Fig. 2a. Further, the discharge products were directly observed by scanning electron microscope (SEM) in Fig. 2c. All the products are toroidal particles with obvious layering. These are quite similar to the toroidal aggregates in a $\mathrm{Li}_{2} \mathrm{O}_{2}$-only discharged cathode ${ }^{32,33}$, which may suggest that the $\mathrm{LiOH}$ was derived from $\mathrm{Li}_{2} \mathrm{O}_{2}$ in the presence of $\mathrm{H}_{2} \mathrm{O}$ in electrolytes by persisting the similar shape. The charged cathode becomes more porous after decomposition of the discharge products in Fig. $2 \mathrm{~d}$ in comparison to the fresh cathode in Fig. 2e. These results indicate that the low charge overpotentials demonstrated in Fig. 1 and Supplementary Fig. 3 resulted from the electrochemical decomposition of $\mathrm{LiOH}$.

Roles of $\mathrm{Ru}$ and $\mathrm{MnO}_{2}$ during discharge and charge. In the $\mathrm{Ru} / \mathrm{MnO}_{2} / \mathrm{SP}$ cathode, all the components of $\mathrm{Ru}^{12,13}, \mathrm{MnO}_{2}$ (ref. 34) and $\mathrm{SP}^{35}$ nanoparticles can act as oxygen reduction reaction catalysts. However, in the charging processes either SP or $\mathrm{MnO}_{2}$ supported on $\mathrm{SP}\left(\mathrm{MnO}_{2} / \mathrm{SP}\right)$ did not show any plateaus at $\sim 3.2 \mathrm{~V}$ but instead at $>3.6 \mathrm{~V}$ (Supplementary Figs 8 and 9). Only the $\mathrm{Ru} / \mathrm{SP}$ as revealed in Supplementary Fig. 10 presented low charge potentials. This suggests good catalytic activity of $\mathrm{Ru}$ nanoparticles on the decomposition of LiOH. Fig. 3 shows 50 cycles of discharge and charge of the $\mathrm{Li}-\mathrm{O}_{2}$ cell with the $\mathrm{Ru} / \mathrm{SP}$ cathode. The charge potentials are sustained at $\sim 3.20 \mathrm{~V}$ in the initial few cycles, and then quickly are increased to $\sim 3.65 \mathrm{~V}$ in
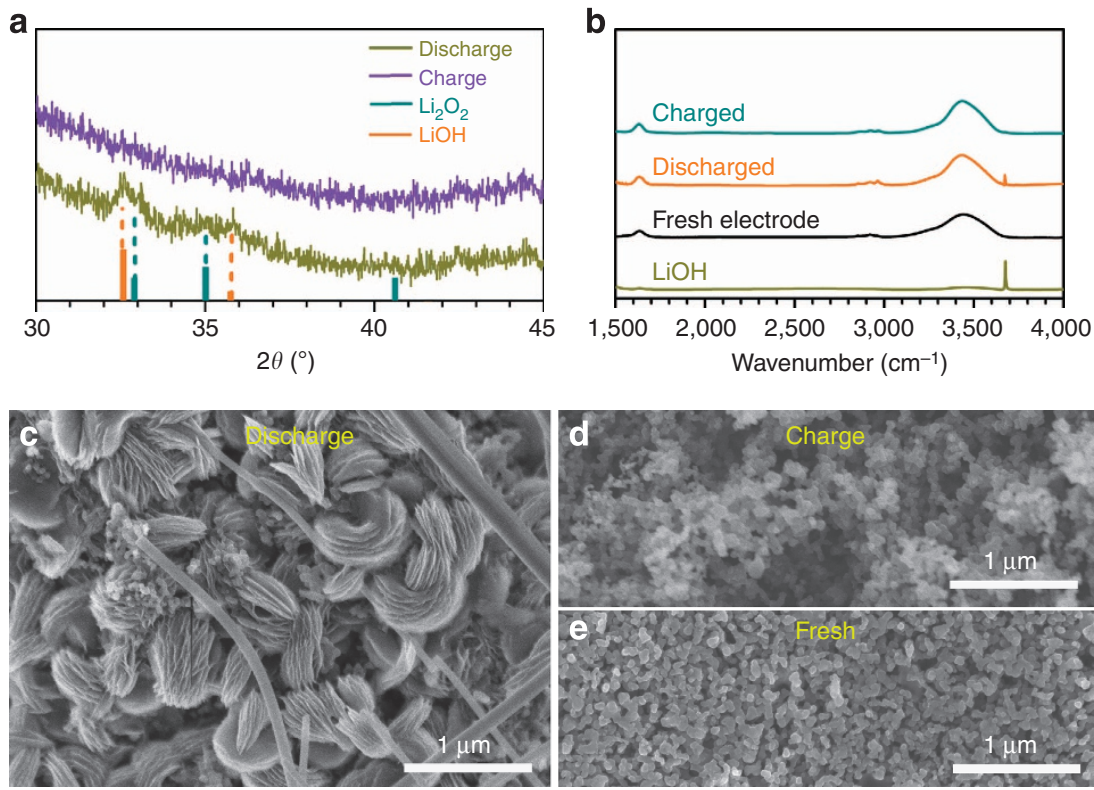

Figure 2 | Characterization of the discharged/charged cathodes. (a) Ex situ XRD patterns of the discharged and charged $\mathrm{Ru} / \mathrm{MnO}_{2} / \mathrm{SP}$ cathodes in DMSO-based electrolyte with 120 p.p.m. $\mathrm{H}_{2} \mathrm{O}$. (b) IR spectra of the charged and discharge cathodes. (c,d) SEM images of the discharged and charged cathodes, in comparison to the fresh cathode (e) 
the tenth cycle and beyond. It indicates that the majority of the discharge product $\mathrm{Li}_{2} \mathrm{O}_{2}$ after multiple cycles cannot be converted to $\mathrm{LiOH}$, because the p.p.m.-leveled $\mathrm{H}_{2} \mathrm{O}$ in the electrolyte was gradually consumed in the charging processes to produce $\mathrm{H}_{2} \mathrm{O}_{2}$. Hence, $\mathrm{MnO}_{2}$ (EMD), the best disproportionation catalyst of $\mathrm{H}_{2} \mathrm{O}_{2}$ (ref. 36), was incorporated into $\mathrm{Ru} / \mathrm{SP}$ to regenerate $\mathrm{H}_{2} \mathrm{O}$ via $2 \mathrm{H}_{2} \mathrm{O}_{2(\mathrm{l})} \rightarrow 2 \mathrm{H}_{2} \mathrm{O}_{(\mathrm{l})}+\mathrm{O}_{2(\mathrm{~g})}$ and make $\mathrm{H}_{2} \mathrm{O}$ circulate during cycles and improve cycling stability of the $\mathrm{Li}-\mathrm{O}_{2}$ cell.

Rate capability and cycling stability. The $\mathrm{Li}-\mathrm{O}_{2}$ cell with $\mathrm{Ru} / \mathrm{MnO}_{2} / \mathrm{SP}$ and the DMSO-based electrolyte containing p.p.m.-leveled $\mathrm{H}_{2} \mathrm{O}$ was examined at varied current densities, as shown in Fig. 4a. The polarization is obviously increased with the current density from 250 to 500 and $1,000 \mathrm{mAg}^{-1}$. The overpotential in the discharging and charging process at $250 \mathrm{~mA} \mathrm{~g}^{-1}$ is $0.11 \mathrm{~V}$ and $0.21 \mathrm{~V}$, respectively, leading to a small discharge/ charge potential gap of $0.32 \mathrm{~V}$. The $\mathrm{Li}-\mathrm{O}_{2}$ cell was continuously discharged and charged at $500 \mathrm{mAg}^{-1}$ for 200 cycles and $\sim 800 \mathrm{~h}$, and the selected runs of discharge and charge are shown in Fig. 4b. The discharge and charge curves during the first 150

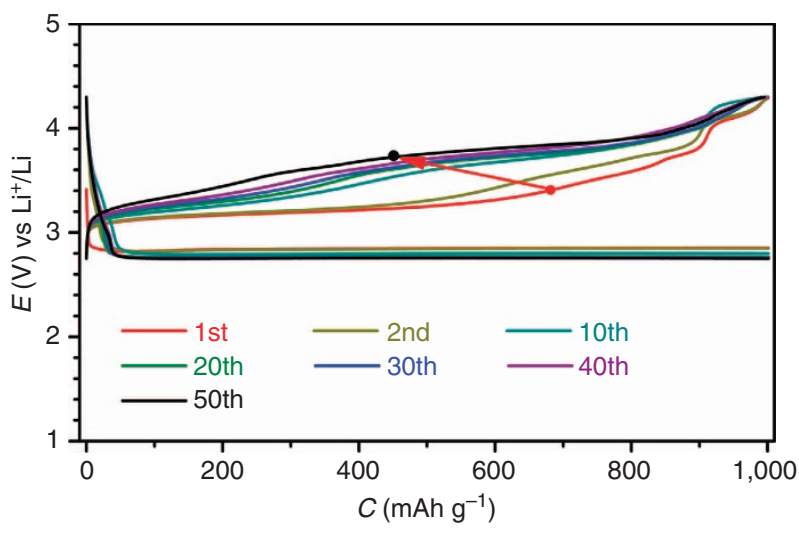

Figure 3 | Discharge/charge profiles of the $\mathbf{L i}-\mathrm{O}_{2}$ cell with $\mathrm{Ru} / \mathrm{SP}$. The charge potentials are steeply increased with cycles. Rate: $250 \mathrm{~mA} \mathrm{~g}^{-1}$. cycles are almost overlapped except the first charge. A slight charge potential increase beyond the 150 cycles can also be observed, which could be related to the electrolyte instability during many cycles (Supplementary Fig. 11) ${ }^{37,38}$. This indicates superior cycling stability of the $\mathrm{Li}-\mathrm{O}_{2}$ cell, which is in sharp contrast to that without $\mathrm{MnO}_{2}$ in Fig. 3. The discharge and charge capacities in the 200 cycles are almost constant, and the corresponding coulombic efficiency in each run is approaching 98\% (Fig. 4c), indicative of good reversibility. This may be partially benefited from the conversion of chemically active $\mathrm{Li}_{2} \mathrm{O}_{2}$ to $\mathrm{LiOH}$. The reversible formation and decomposition of $\mathrm{LiOH}$ and $\mathrm{Li}_{2} \mathrm{O}_{2}$ during the 200 cycles are further confirmed by ex situ XRD patterns in Supplementary Fig. 12 and SEM images in Supplementary Fig. 13 (Supplementary Note 3 ). The low charge potentials sustained for so many cycles, to the best of our knowledge, have never been achieved before. The small discharge/ charge potential gap and good cycling stability of the $\mathrm{Li}-\mathrm{O}_{2}$ cell are rewarded by the 'water catalysis' at the $\mathrm{Ru} / \mathrm{MnO}_{2} / \mathrm{SP}$ cathode.

Reaction mechanism. The equilibrium potential of $\mathrm{LiOH}$ in an

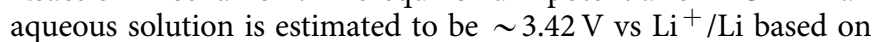
Nernst equation $^{34,39}$. However, in this studied electrolyte system the trace amount of $\mathrm{H}_{2} \mathrm{O}$ and $\mathrm{LiClO}_{4}$ are both the solutes and DMSO is the solvent. The equilibrium potential of $\mathrm{LiOH}$ is dependent on the concentration of $\mathrm{H}_{2} \mathrm{O}$, and it can be roughly estimated to be $\sim 3.20 \mathrm{~V}$, considering a concentration of 100 p.p.m. of $\mathrm{H}_{2} \mathrm{O}$ in the electrolyte (see the estimation process in Supplementary Methods). This is in good agreement with the observed low charge potential plateaus in all the widely employed electrolytes DMSO-, DME-, G3- and G4-based electrolytes for $\mathrm{Li}-\mathrm{O}_{2}$ cells in Figs 1 and 4 and Supplementary Fig. 3.

Based on the above results, a mechanism for the discharging and charging process of the cell with $\mathrm{Ru} / \mathrm{MnO}_{2} / \mathrm{SP}$ and the electrolyte containing a trace amount of $\mathrm{H}_{2} \mathrm{O}$ can be proposed and schematically described in Fig. 5a. On discharging, $\mathrm{O}_{2}$ accepts electrons via the external circuit and is reduced to generate the primary discharge product $\mathrm{Li}_{2} \mathrm{O}_{2}$ (refs $40-42$ ). At the same time, the $\mathrm{Li}_{2} \mathrm{O}_{2}$ reacts with $\mathrm{H}_{2} \mathrm{O}$ from the electrolyte and is converted to $\mathrm{LiOH}$ via Steps (i and ii). Although Step (i) is an equilibrium ${ }^{26}$,
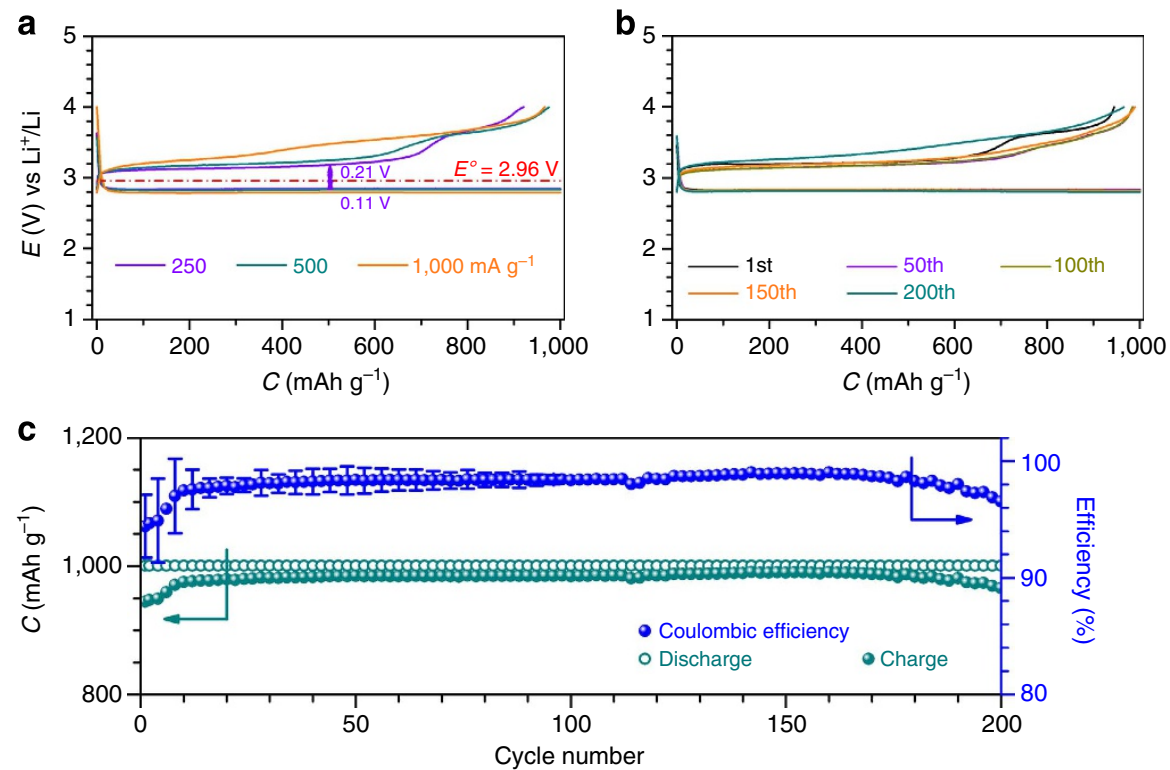

Figure 4 | Rate capability and cycling performance of the $\mathbf{L i}-\mathbf{O}_{\mathbf{2}}$ cells with $\mathbf{R u} / \mathbf{M n O}_{\mathbf{2}} / \mathbf{S P}$. (a) Discharge/charge profiles of the tenth run at varied current densities from 250 to 500 and $1,000 \mathrm{mAg}^{-1}$. (b) Discharge/charge profiles of the selected runs over the $200 \mathrm{cycles}$ at $500 \mathrm{mAg}^{-1}$. The cell was at rest for $1 \mathrm{~min}$ between each run. (c) Plot of discharge/charge capacities and the corresponding coulombic efficiencies against cycle number and error bars (s.e.m.) in the first 100 cycles. 
a

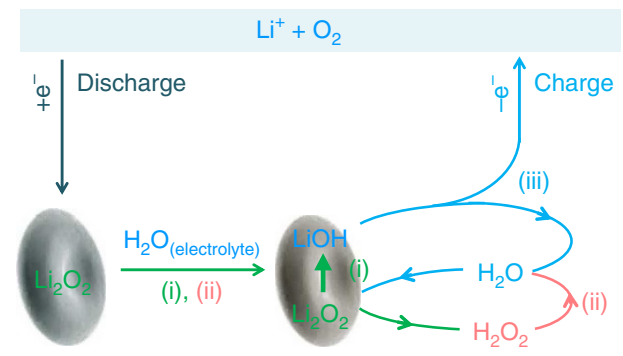

(i) $\mathrm{Li}_{2} \mathrm{O}_{2(\mathrm{~s})}+2 \mathrm{H}_{2} \mathrm{O}_{(\mathrm{l})} \rightarrow 2 \mathrm{LiOH}_{(\mathrm{s})}+\mathrm{H}_{2} \mathrm{O}_{2(\text { (l) }}$

(ii) $\mathrm{H}_{2} \mathrm{O}_{2(\text { (l) }} \stackrel{\mathrm{MnO}_{2}}{\rightarrow} \mathrm{H}_{2} \mathrm{O}_{(\mathrm{l})}+1 / 2 \mathrm{O}_{2(\mathrm{~g})}$

(iii) $2 \mathrm{LiOH}_{(\mathrm{s})} \stackrel{\mathrm{Ru}}{\rightarrow} 2 \mathrm{Li}^{+}+1 / 2 \mathrm{O}_{2(\mathrm{~g})}+\mathrm{H}_{2} \mathrm{O}_{(\mathrm{l})}+2 \mathrm{e}^{-}$

Total: $\mathrm{Li}_{2} \mathrm{O}_{2} \leftrightarrow 2 \mathrm{Li}^{+}+\mathrm{O}_{2}+2 \mathrm{e}^{-}$ b

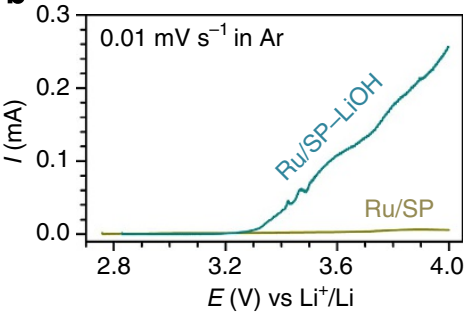

C

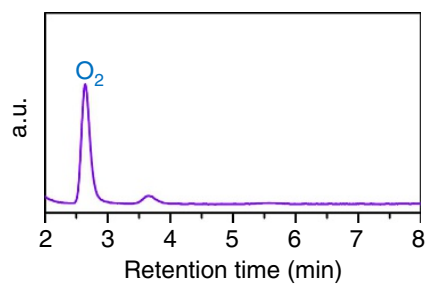

Figure 5 | Proposed reaction mechanism, LSV and gas analysis. (a) (i) is a spontaneous process; (ii) is promoted over $\mathrm{MnO}_{2}$ nanoparticles in $\mathrm{Ru} / \mathrm{MnO}_{2} / \mathrm{SP}$; and oxidation of $\mathrm{LiOH}$ in (iii) occurs at low charge overpotentials over Ru nanoparticles. (b) Linear scanning voltammetry (LSV) curves of the $\mathrm{Ru} / \mathrm{SP}$ electrodes with and without $\mathrm{LiOH}$ under Ar atmosphere. (c) Gas chromatography (GC) analysis on the gas evolved in a charging process.

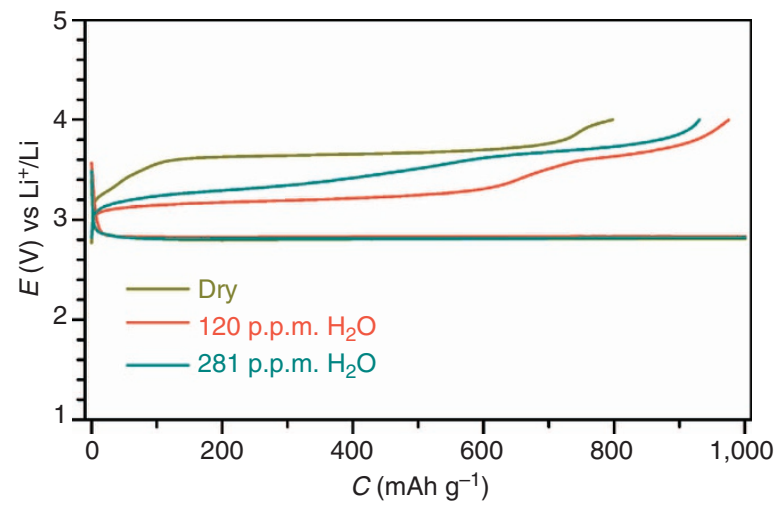

Figure 6 | Discharge/charge profiles of the fifth cycles of the $\mathrm{Li}-\mathrm{O}_{2}$ cells with $\mathbf{R u} / \mathbf{M n O}_{2} / \mathbf{S P}$. The applied DMSO-based electrolytes are dried over a Li foil, and contain 120 and 281 p.p.m. of $\mathrm{H}_{2} \mathrm{O}$. Rate: $500 \mathrm{mAg}^{-1}$.

it can be largely promoted to move forward by the conversion of one of the products $\mathrm{H}_{2} \mathrm{O}_{2}$ to $\mathrm{H}_{2} \mathrm{O}$ over $\mathrm{MnO}_{2}$ via Step (ii) ${ }^{36}$. The two Steps ( $\mathrm{i}$ and ii) occur sequentially, and quickly transform $\mathrm{Li}_{2} \mathrm{O}_{2}$ to $\mathrm{LiOH}$ as long as $\mathrm{H}_{2} \mathrm{O}$ remains in the electrolyte. This has been confirmed by the presence of substantial $\mathrm{LiOH}$ in discharged cathodes as revealed by both of the XRD patterns and the IR spectra in Fig. 2. This is consistent with the observations of Aetukuri et al. ${ }^{25}$, and Schwenke et al. ${ }^{26}$, where the $\mathrm{H}_{2} \mathrm{O}$ in electrolytes is possibly consumed by the employed $\mathrm{Li}$ anode or saturated by the product $\mathrm{LiOH}$, and the lack of a promoter like $\mathrm{MnO}_{2}$ for Step (ii) made the equilibrium reaction in Step (i) to move backward and result in the major discharge product $\mathrm{Li}_{2} \mathrm{O}_{2}$ as detected.

In the following charging process, the resultant $\mathrm{LiOH}$ can be directly oxidized via Step (iii) to regenerate $\mathrm{H}_{2} \mathrm{O}$ at low charge potentials, by which the residual $\mathrm{Li}_{2} \mathrm{O}_{2}$ is then converted to $\mathrm{LiOH}$ via Steps (i and ii) and oxidized. To demonstrate the feasibility of Step (iii), commercial $\mathrm{LiOH}$ was ball-milled and then thoroughly mixed with Ru/SP with a ratio of 30:70 (wt/wt). The electrodes of $\mathrm{Ru} / \mathrm{SP}$ with and without $\mathrm{LiOH}$ under $\mathrm{Ar}$ atmosphere were subjected to linear scanning voltammetry (LSV) at a low scan rate of $0.01 \mathrm{mV} \mathrm{s}^{-1}$ as depicted in Fig. 5b. The Ru/SP electrode incorporated with $\mathrm{LiOH}$ presents significant oxidation currents and an oxidation onset potential of $\sim 3.27 \mathrm{~V}$ in Fig. 5b, which is
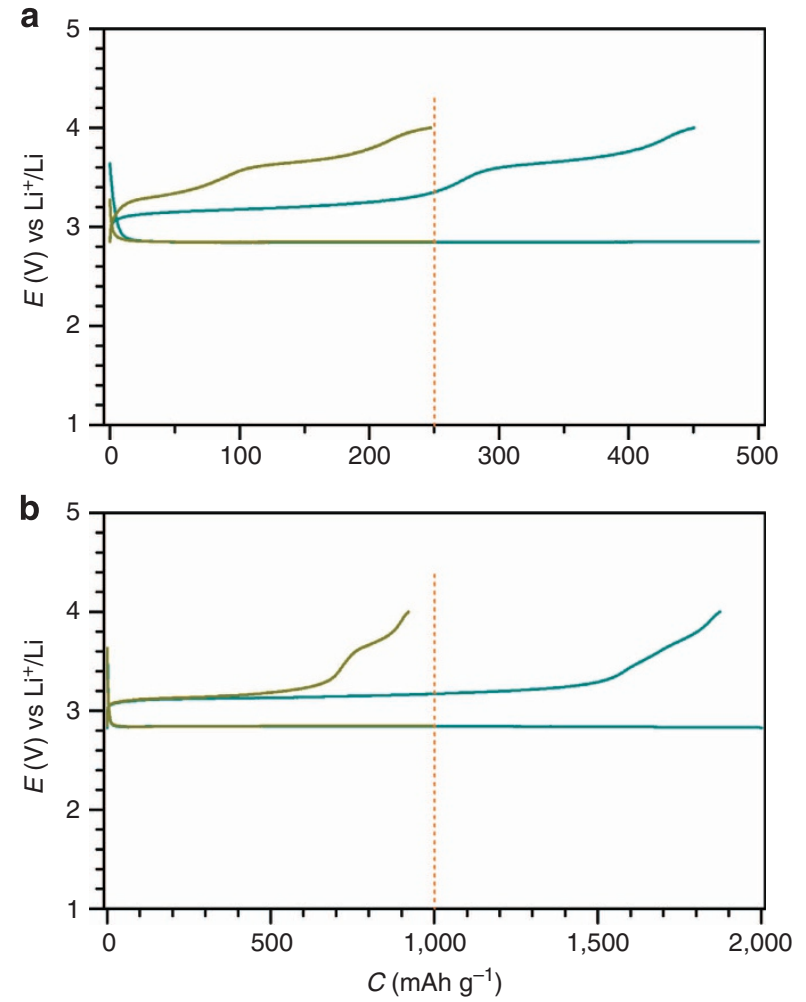

Figure 7 | Discharge/charge profiles of the fifth cycles of the $\mathrm{Li}-\mathrm{O}_{2}$ cell at $250 \mathrm{mAg}^{-1}$. (a) Discharge capacity is limited for 250 and $500 \mathrm{mAhg}^{-1}$. (b) Discharge capacity is limited for 1,000 and $2,000 \mathrm{mAhg}^{-1}$. The cathode is $\mathrm{Ru} / \mathrm{MnO}_{2} / \mathrm{SP}$ and the DMSO-based electrolyte containing 120 p.p.m. of $\mathrm{H}_{2} \mathrm{O}$ is applied.

in sharp contrast with no oxidation response on the electrode without $\mathrm{LiOH}$. At a carbon electrode pre-filled with $\mathrm{LiOH}$, a high charge potential of $>4.0 \mathrm{~V}$ was reported ${ }^{43}$. This suggests that over $\mathrm{Ru} / \mathrm{SP} \mathrm{LiOH}$ was oxidized at low potentials, though it may be dependent on its morphology and facet orientation and the catalyst. The gas evolved in a charging process can be identified as $\mathrm{O}_{2}$ by a gas chromatography (GC) mounted with a thermal conductivity detector, as evidenced by the sharp GC signal of $\mathrm{O}_{2}$ in Fig. 5c. As shown in the whole discharging and charging 
process in Fig. $5 \mathrm{a}, \mathrm{H}_{2} \mathrm{O}$ is not consumed and can be circulated to behave like a catalyst. The total electrochemical reaction occurring at the oxygen cathode is $2 \mathrm{Li}^{+}+\mathrm{O}_{2}+2 \mathrm{e}^{-} \leftrightarrow \mathrm{Li}_{2} \mathrm{O}_{2}$, consistent with the $\mathrm{Li}-\mathrm{O}_{2}$ cell chemistry.

\section{Discussion}

The dependence of the charge potentials on the concentration of $\mathrm{H}_{2} \mathrm{O}$ in electrolytes is shown in Fig. 6. In the dried DMSO-based electrolyte, one charge potential plateau can be obtained at $\sim 3.65 \mathrm{~V}$, which is attributed to the oxidation of $\mathrm{Li}_{2} \mathrm{O}_{2}$ and in good agreement with the literatrues ${ }^{10-15}$. When there is 120 p.p.m. of water in the electrolyte, the charge potential plateau is significantly reduced to $\sim 3.2 \mathrm{~V}$. This has been confirmed to the oxidation of $\mathrm{LiOH}$ that can be quickly converted from the primary discharge product $\mathrm{Li}_{2} \mathrm{O}_{2}$ via the sequential Steps (i and ii) in Fig. 5a over the catalyst of $\mathrm{Ru} / \mathrm{MnO}_{2} / \mathrm{SP}$ in both the discharging and charging processes. However, when the concentration of water in the electrolyte is increased to 281 p.p.m., the charge potential plateau is shortened and increased. It may be induced by the $\mathrm{LiOH}$ on the surface of the discharge product, which is surrounded/adsorbed by $\mathrm{H}_{2} \mathrm{O}$ molecules in the electrolyte, and hence has high oxidation potentials following the Nernst equation ${ }^{17,32,33}$.

In addition, by controlling the discharge depth of the $\mathrm{Li}-\mathrm{O}_{2}$ cells, the discharge product can be ranged from $\mathrm{LiOH}$ only to a majority of $\mathrm{Li}_{2} \mathrm{O}_{2}$ plus $\mathrm{LiOH}$ with the same amount of electrolytes used in cells. The cathode with a relatively small discharge capacity of $250 \mathrm{mAh} \mathrm{g}^{-1}$ was covered with $\mathrm{LiOH}$, on which no $\mathrm{Li}_{2} \mathrm{O}_{2}$ was detected by iodometric titration. It is in the shape of thin disks as shown in Supplementary Fig. 14 (refs 25,33). In the following charging process, the potentials are increased to $\sim 3.65 \mathrm{~V}$ and similar to that with 281 p.p.m. of $\mathrm{H}_{2} \mathrm{O}$ in electrolytes in Fig. 6 . The low charge potentials at $\sim 3.20 \mathrm{~V}$ can be observed again when the discharge capacity is increased to 500, 1,000 and 2,000 $\mathrm{mAh} \mathrm{g}^{-1}$, as shown in Fig. 7. At large discharge capacities, the $\mathrm{H}_{2} \mathrm{O}$ molecules in the electrolyte can be consumed by $\mathrm{Li}_{2} \mathrm{O}_{2}$, producing surface-clean $\mathrm{LiOH} / \mathrm{Li}_{2} \mathrm{O}_{2}$ in the cathode. This suggests that the relative amounts of $\mathrm{H}_{2} \mathrm{O}, \mathrm{LiOH}$ and $\mathrm{Li}_{2} \mathrm{O}_{2}$ coexisting at a cathode side affect the charging overpotentials. The detailed formation/decomposition mechanism of $\mathrm{LiOH}$ and $\mathrm{Li}_{2} \mathrm{O}_{2}$ in the presence of water in electrolytes and the dependence of their decomposition potentials on their morphologies deserve further investigation.

The 'water catalysis' at the oxygen cathode side has been demonstrated to reduce the charge overpotentials to $\sim 0.24 \mathrm{~V}$, corresponding to $\sim 3.20 \mathrm{~V}$ vs $\mathrm{Li}^{+} / \mathrm{Li}$ and provides a possible solution to the current challenges of $\mathrm{Li}-\mathrm{O}_{2}$ cells. With the $\mathrm{Ru} / \mathrm{MnO}_{2} / \mathrm{SP}$ cathode and the DMSO-based electrolyte containing p.p.m.-leveled $\mathrm{H}_{2} \mathrm{O}$, the $\mathrm{Li}-\mathrm{O}_{2}$ cell presents a small discharge/ charge potential gap of $0.32 \mathrm{~V}$ and superior cycling stability of 200 cycles $\sim 800 \mathrm{~h}$. These have not been achieved before, and are rewarded by the proposed reaction mechanism. Although the $\mathrm{LiFePO}_{4}$ applied in cells is not a practical anode of $\mathrm{Li}-\mathrm{O}_{2}$ cells, the reaction mechanism at the oxygen cathode may be extended to a practical $\mathrm{Li}-\mathrm{O}_{2}$ cell by using a $\mathrm{Li}^{+}$ion-conducting ceramic membrane to separate the electrolyte with water and the $\mathrm{Li}$ anode ${ }^{2,39}$. This could also alleviate the carbon-related side reactions by converting the chemically active $\mathrm{Li}_{2} \mathrm{O}_{2}$ to $\mathrm{LiOH}$, and it will make the cheap and lightweight carbon possible as cathodes in $\mathrm{Li}-\mathrm{O}_{2}$ cells, which has been suggested to avoid. This investigation will enable the cell to operate in ambient air by eliminating $\mathrm{CO}_{2}$ and advance the $\mathrm{Li}-\mathrm{O}_{2}$ /air cell technology.

\section{Methods}

Materials preparation. Electrolytic $\mathrm{MnO}_{2}\left(\mathrm{EMD}, \gamma-\mathrm{MnO}_{2}\right)$ was received from $\mathrm{TOSOH}$, Japan and ball-milled to nanometre scale. $\mathrm{Ru} / \mathrm{SP}$ was synthesized as follows: $85 \mathrm{mg}$ of SP was stirred into a solution of ethylene glycol (EG, purity of $>99.5 \%$, Wako Chemicals) containing $7.5 \mathrm{mg}$ of $\mathrm{Ru}$ in $\mathrm{RuCl}_{3} \bullet \mathrm{xH}_{2} \mathrm{O}$ (purity of $36 \sim 42$ wt\% based on $\mathrm{Ru}$, Wako Chemicals), and its $\mathrm{pH}$ was adjusted to 13 with $0.1 \mathrm{M}$ of $\mathrm{NaOH}$ in EG. The suspension was then heated to $160^{\circ} \mathrm{C}$ for $3 \mathrm{~h}$ with flowing $\mathrm{N}_{2}$. After cooling to $80^{\circ} \mathrm{C}$, its $\mathrm{pH}$ was adjusted to 3 using $0.1 \mathrm{M} \mathrm{HCl}$ and the resulting mixture was further stirred for $12 \mathrm{~h}$. The final product $\mathrm{Ru} / \mathrm{SP}$ was centrifuged, washed with de-ionized water until the solution $\mathrm{pH}$ reached $\sim 7$ and dried at $80^{\circ} \mathrm{C}$ in a vacuum oven for $12 \mathrm{~h}$. For the preparation of $\mathrm{MnO}_{2} / \mathrm{Ru} / \mathrm{SP}$, the as-synthesized $\mathrm{Ru} / \mathrm{SP}$ and $\mathrm{MnO}_{2}$ nanoparticles with a weight ratio $\mathrm{Ru} / \mathrm{MnO}_{2} / \mathrm{SP}=7.5: 7.5: 85$ were sonicated into an ethanol aqueous solution for $3 \mathrm{~h}$ and stirred overnight. Then, the product $\mathrm{MnO}_{2} / \mathrm{Ru} / \mathrm{SP}$ was collected and dried at $80^{\circ} \mathrm{C}$ under vacuum for $12 \mathrm{~h}$.

DMSO, DME, G3 and G4 were firstly dried over $4 \AA$ molecular sieves and then using $\mathrm{Li}$ metal. The $\mathrm{Li}$ salts of $\mathrm{LiClO}_{4}$ and lithium bis(fluorosulfonyl)imide were used as received from Wako Chemicals. The water in the prepared electrolytes was from the Li salts and measured on a desk-top Karl-Fisher Titration instrument.

Cell assembly. The electrode film composed of $\mathrm{Ru} / \mathrm{MnO}_{2} / \mathrm{SP}$ or $\mathrm{Ru} / \mathrm{SP}$ and PTFE (A dispersion of $60 \mathrm{wt} \%$, Du Pont-Mitsui Fluorochemicals Co. Ltd.) with a ratio of $85: 15 \mathrm{wt} \%$ was rolled with a glass rod. The mass loading of $\mathrm{Ru} / \mathrm{MnO}_{2} / \mathrm{SP}$ or $\mathrm{Ru} / \mathrm{SP}$ is $\sim 0.5 \mathrm{mg} \mathrm{cm}^{-2}$. The electrode film was pressed onto a hydrophobic carbon paper (SIGRACET Gas Diffusion Media, Type GDL 35BA) to work as a cathode. The anode was consisted of $\mathrm{LiFePO}_{4}$ (Sumitomo Osaka Cement), SP and PTFE (70/20/10) pressed on an Al mesh. The amount of DMSO- and DME-based electrolytes in a coin cell was $100 \mu$ land G3- and G4-based electrolyte was $50 \mu \mathrm{l}$ considering their different vapour pressures. The employed separator was a glass microfibre filter paper (GF/A, Whatman). The $\mathrm{Li}-\mathrm{O}_{2}$ cell assembly in 2032 coin cells was conducted in an Ar-filled glove box that has a dew point of around $-90{ }^{\circ} \mathrm{C}\left(\sim 0.1\right.$ p.p.m. of $\left.\mathrm{H}_{2} \mathrm{O}\right)$ and $\mathrm{O}_{2}$ content below 5 p.p.m.. The cells stored in a glass chamber with a volume capacity of $650 \mathrm{ml}$ were purged with $\mathrm{O}_{2}(99.999 \%)$ before electrochemical tests.

Characterization and measurements. The contact angles of electrolytes on the cathode were examined on AST Products with a model of Optima. The BET surface area of $\mathrm{Ru} / \mathrm{MnO}_{2} / \mathrm{SP}$ was measured to be $70.6 \mathrm{~m}^{2} \mathrm{~g}^{-1}$ on Belsorp 18 via nitrogen adsorption-desorption. XRD was performed on a Bruker D8 Advanced diffractometer with $\mathrm{Cu} \mathrm{K} \alpha(\lambda=1.5406 \AA)$ radiation with a scan rate of $0.016^{\circ}$ per s Galvanostatic discharge/charge was conducted on a Hokuto discharging/charging system. All the electrochemical measurements were conducted at $25^{\circ} \mathrm{C}$. The specific capacities and currents are based on the mass of $\mathrm{Ru} / \mathrm{MnO}_{2} / \mathrm{SP}$ or $\mathrm{Ru} / \mathrm{SP}$ in cathodes. The discharged and charged cathodes were extracted in the glove box and washed with dried dimethoxyethane. SEM was obtained on Hitachi S4800. The $\mathrm{Ru} / \mathrm{MnO}_{2} / \mathrm{SP}$ was mixed with $\mathrm{KBr}$ and then pressed to a pellet for Fourier transform infrared spectroscope (FTIR) characterization on a JASCO instrument of FT/IR-6,200 from 2,000 to $400 \mathrm{~cm}^{-1}$ with a resolution of $2 \mathrm{~cm}^{-1}$. The electrolytes during cycles were collected by washing the glass fibre filter separators with acetone- $\mathrm{d}_{6}$, and subjected to ${ }^{1} \mathrm{H}$ NMR (Bruker, $500 \mathrm{MHz}$ ).

\section{References}

1. Abraham, K. M. \& Jiang, Z. A polymer electrolyte-based rechargeable lithium/oxygen battery. J. Electrochem. Soc. 143, 1-5 (1996).

2. Girishkumar, G., McCloskey, B., Luntz, A. C., Swanson, S. \& Wilcke, W. Lithium-air battery: promise and challenges. J. Phys. Chem. Lett. 1, 2193-2203 (2010).

3. Bruce, P. G., Freunberger, S. A., Hardwick, L. J. \& Tarascon, J.-M. Li-O 2 and Li-S batteries with high energy storage. Nat. Mater. 11, 19-29 (2012).

4. Thotiyl, M. M. O., Freunberger, S. A., Peng, Z. \& Bruce, P. G. The carbon electrode in nonaqueous $\mathrm{Li}^{-\mathrm{O}_{2}}$ cells. J. Am. Chem. Soc. 135, 494-500 (2013).

5. Gallant, B. M. et al. Chemical and morphological changes of $\mathrm{Li}^{-} \mathrm{O}_{2}$ battery electrodes upon cycling. J. Phys. Chem. C 116, 20800-20805 (2012).

6. Mizuno, F., Nakanishi, S., Kotani, Y., Yokoishi, S. \& Iba, H. Rechargeable Li-air batteries with carbonate-based liquid electrolytes. Electrochemistry 78, 403-405 (2010).

7. Freunberger, S. A. et al. Reactions in the rechargeable lithium- $\mathrm{O}_{2}$ battery with alkyl carbonate electrolytes. J. Am. Chem. Soc. 133, 8040-8047 (2011)

8. Xiao, J. et al. Investigation of the rechargeability of $\mathrm{Li}^{-} \mathrm{O}_{2}$ batteries in non-aqueous electrolyte. J. Power Sources 196, 5674-5678 (2011).

9. McCloskey, B. D. et al. Twin problems of interfacial carbonate formation in non-aqueous $\mathrm{Li}_{-} \mathrm{O}_{2}$ batteries. J. Phys. Chem. Lett. 3, 997-1001 (2012).

10. Peng, Z., Freunberger, S., Chen, Y. \& Bruce, P. G. A reversible and higher-rate Li- $\mathrm{O}_{2}$ battery. Science 337, 563-566 (2012).

11. Thotiyl, M. M. O. et al. A stable cathode for the aprotic $\mathrm{Li}_{-} \mathrm{O}_{2}$ battery. Nat Mater. 12, 1050-1056 (2013).

12. Li, F. et al. $\mathrm{Ru} / \mathrm{ITO}$ : a carbon-free cathode for nonaqueous $\mathrm{Li}^{-} \mathrm{O}_{2}$ battery. Nano Lett. 13, 4702-4707 (2013).

13. Li, F. et al. $\mathrm{Li}_{-} \mathrm{O}_{2}$ battery based on highly efficient $\mathrm{Sb}$-doped tin oxide supported Ru nanoparticles. Adv. Mater. 26, 4659-4664 (2014). 
14. Li, F. et al. Superior performance of a $\mathrm{Li}-\mathrm{O}_{2}$ battery with metallic $\mathrm{RuO}_{2}$ hollow spheres as the carbon-free cathode. Adv. Energy Mater. doi:10.1002/aenm.201500294 (2015).

15. Lu, J. et al. Aprotic and aqueous $\mathrm{Li}^{-\mathrm{O}_{2}}$ batteries. Chem. Rev. 114, 5611-5640 (2014).

16. Li, F., Zhang, T. \& Zhou, H. Challenges of non-aqueous $\mathrm{Li}^{-} \mathrm{O}_{2}$ batteries: electrolytes, catalysts, and anodes. Energy Environ. Sci. 6, 1125-1141 (2013).

17. Shao, Y. et al. Making Li-air batteries rechargeable: material challenges. $A d v$. Funct. Mater. 23, 987-1004 (2013).

18. Lu, Y.-C. \& Shao-Horn, Y. Probing the reaction kinetics of the charge reactions of nonaqueous $\mathrm{Li}^{-\mathrm{O}_{2}}$ batteries. J. Phys. Chem. Lett. 4, 93-99 (2013).

19. Kang, S. Y., Mo, Y., Ong, S. P. \& Ceder, G. A facile mechanism for recharging $\mathrm{Li}_{2} \mathrm{O}_{2}$ in $\mathrm{Li}_{-} \mathrm{O}_{2}$ batteries. Chem. Mater. 25, 3328-3336 (2013).

20. Chen, Y., Freunberger, S. A., Peng, Z., Fontaine, O. \& Bruce, P. G. Charging a Li- $\mathrm{O}_{2}$ battery using a redox mediator. Nat. Chem. 5, 489-494 (2013).

21. Lim, H. D. et al. Superior rechargeability and efficiency of lithium-oxygen batteries: hierarchical air electrode architecture combined with a soluble catalyst. Angew. Chem. Int. Ed. 53, 3926-3931 (2014).

22. Meini, S., Solchenbach, S., Piana, M. \& Gasteiger, H. A. The role of electrolyte solvent stability and electrolyte impurities in the electrooxidation of $\mathrm{Li}_{2} \mathrm{O}_{2}$ in $\mathrm{Li}_{2} \mathrm{O}_{2}$ batteries. J. Electrochem. Soc. 161, A1306-A1314 (2014).

23. Wang, Y. \& Xia, Y. Li- $\mathrm{O}_{2}$ batteries: an agent for change. Nat. Chem. 5, 445-447 (2013).

24. Meini, S., Piana, M., Tsiouvaras, N., Garsuch, A. \& Gasteiger, H. A. The effect of water on the discharge capacity of a non-catalysed carbon cathode for $\mathrm{Li}^{-\mathrm{O}_{2}}$ batteries. Electrochem. Solid State Lett. 15, A45-A48 (2012).

25. Aetukuri, N. B. et al. Solvating additives drive solution-mediated electrochemistry and enhance toroid growth in non-aqueous $\mathrm{Li}^{-} \mathrm{O}_{2}$ batteries Nat. Chem. 7, 50-56 (2015).

26. Schwenke, K. U., Metzger, M., Restle, T., Piana, M. \& Gasteiger, H. A. The influence of water and protons on $\mathrm{Li}_{2} \mathrm{O}_{2}$ crystal growth in aprotic $\mathrm{Li}-\mathrm{O}_{2}$ cells. J. Electrochem. Soc. 162, A573-A585 (2015).

27. Guo, Z., Dong, X., Yuan, S., Wang, Y. \& Xia, Y. Humidity effect on electrochemical performance of $\mathrm{Li}-\mathrm{O}_{2}$ batteries. J. Power Sources 264, 1-7 (2014).

28. Cho, M. H. et al. The effects of moisture contamination in the $\mathrm{Li}^{-} \mathrm{O}_{2}$ battery. J. Power Sources 268, 565-574 (2014).

29. Aravindan, V., Gnanaraj, J., Madhavi, S. \& Liu, H. K. Lithium-ion conducting electrolyte salts for lithium batteries. Chem. Eur. J. 17, 14326-14346 (2011).

30. Black, R. et al. Screening for superoxide reactivity in $\mathrm{Li}-\mathrm{O}_{2}$ batteries: effect on $\mathrm{Li}_{2} \mathrm{O}_{2} / \mathrm{LiOH}$ crystallization. J. Am. Chem. Soc. 134, 2902-2905 (2012).

31. McCloskey, B. D. et al. Combining accurate $\mathrm{O}_{2}$ and $\mathrm{Li}_{2} \mathrm{O}_{2}$ assays to separate discharge and charge stability limitations in nonaqueous $\mathrm{Li}-\mathrm{O}_{2}$ batteries. J. Phys. Chem. Lett. 4, 2989-2993 (2013).

32. Oh, S. H., Black, R., Pomerantseva, E., Lee, J.-H. \& Nazar, L. F. Synthesis of a metallic mesoporous pyrochlore as a catalyst for lithium- $\mathrm{O}_{2}$ batteries. Nat . Chem. 4, 1004-1010 (2012).

33. Mitchell, R. R., Gallant, B. M., Shao-Horn, Y. \& Thompson, C. V. Mechanisms of morphological evolution of $\mathrm{Li}_{2} \mathrm{O}_{2}$ particles during electrochemical growth. J. Phys. Chem. Lett. 4, 1060-1064 (2013).

34. Cheng, F. \& Chen, J. Metal-air batteries: from oxygen reduction electrochemistry to cathode catalysts. Chem. Soc. Rev. 41, 2172-2192 (2012)
35. Jung, H.-G., Hassoun, J., Park, J.-B., Sun, Y.-K. \& Scrosati, B. An improved high-performance lithium-air battery. Nat. Chem. 4, 579-585 (2012).

36. Giordani, V., Freunberger, S. A., Bruce, P. G., Tarascon, J.-M. \& Larcher, D. $\mathrm{H}_{2} \mathrm{O}_{2}$ decomposition reaction as selecting tool for catalysts in $\mathrm{Li}-\mathrm{O}_{2}$ cells. Electrochem. Solid State Lett. 13, A180-A183 (2010).

37. Trahan, M. J., Mukerjee, S., Plichta, E., Hendrickson, M. A. \& Abraham, K. M. Studies of Li-air cells utilizing dimethyl sulfoxide-based electrolyte. J. Electrochem. Soc. 160, A259-A267 (2013).

38. Sharon, D. et al. Oxidation of dimethyl sulfoxide solutions by electrochemical reduction of oxygen. J. Phys. Chem. Lett. 4, 3115-3119 (2013).

39. Manthiram, A. \& Li, L. Hybrid and aqueous lithium-air batteries. Adv. Energy Mater. 5, 1-17 (2015).

40. Laoire, C. O., Mukerjee, S. \& Abraham, K. M. Elucidating the mechanism of oxygen reduction for lithium-air battery applications. J. Phys. Chem. C 113, 20127-20134 (2009).

41. McCloskey, B. D., Scheffler, R., Speidel, A., Girishkumar, G. \& Luntz, A. C. On the mechanism of nonaqueous $\mathrm{Li}_{-} \mathrm{O}_{2}$ electrochemistry on carbon and its kinetic overpotentials: some implications for Li-air batteries. J. Phys. Chem. C 116, 23897-23905 (2012).

42. Johnson, L. et al. The role of $\mathrm{LiO}_{2}$ solubility in $\mathrm{O}_{2}$ reduction in aprotic solvents and its consequences for $\mathrm{Li}_{2} \mathrm{O}_{2}$ batteries. Nat. Chem. 6, 1091-1099 (2014).

43. Meini, S. et al. Rechargeability of Li-air cathodes pre-filled with discharge products using an ethe-based electrolyte solution: implications for cycle-life of Li-air cells. Phys. Chem. Chem. Phys. 15, 11478-11493 (2013).

\section{Acknowledgements}

The financial supports from Mitsubishi Motors Corporation, the National Basic Research Program of China (2014CB932302) and ALCA project are acknowledged.

\section{Author contributions}

F.L. designed and performed the experiments; S.W. examined water contents in electrolytes and their contact angles; all the authors contributed to the discussion of the manuscript; F.L, H.Z., and A.Y. wrote the manuscript; H.Z. supervised the work

\section{Additional information}

Supplementary Information accompanies this paper at http://www.nature.com/ naturecommunications

Competing financial interests: The authors declare no competing financial interests.

Reprints and permission information is available online at http://npg.nature.com/ reprintsandpermissions/

How to cite this article: Li, F. et al. The water catalysis at oxygen cathodes of lithium-oxygen cells. Nat. Commun. 6:7843 doi: 10.1038/ncomms8843 (2015).

(c) (i) This work is licensed under a Creative Commons Attribution 4.0 International License. The images or other third party material in this article are included in the article's Creative Commons license, unless indicated otherwise in the credit line; if the material is not included under the Creative Commons license, users will need to obtain permission from the license holder to reproduce the material. To view a copy of this license, visit http://creativecommons.org/licenses/by/4.0/ 